OPEN ACCESS

Edited by:

Amelia Kekeletso Ranotsi,

Maluti Adventist College, Lesotho

Reviewed by:

Qun (Bella) Mai,

Government of Western

Australia, Australia

Anupama Nambiar,

Christian Medical College,

India

Smitha Jasper

Christian Medical College,

India

${ }^{*}$ Correspondence:

Resham Bahadur Khatri rkchettri@gmail.com

Specialty section: This article was submitted to Public Health Policy, a section of the journal

Frontiers in Public Health

Received: 14 August 2016 Accepted: 05 July 2017

Published: 21 July 2017

Citation:

Khatri RB, Mishra SR and Khanal V (2017) Female Community Health

Volunteers in Community-Based Health Programs of Nepal:

Future Perspective.

Front. Public Health 5:181. doi: 10.3389/fpubh.2017.00181

\section{Female Community Health Volunteers in Community-Based Health Programs of Nepal: Future Perspective}

\author{
Resham Bahadur Khatri ${ }^{1,2 *}$, Shiva Raj Mishra ${ }^{2}$ and Vishnu Khanal ${ }^{3}$ \\ ${ }^{1}$ Center for Research and Development, Kathmandu, Nepal, ${ }^{2}$ School of Public Health, The University of Queensland, \\ Brisbane, QLD, Australia, ${ }^{3}$ School of Public Health, Curtin University, Perth, WA, Australia
}

Nepal's Female Community Health Volunteers (FCHVs) program started in 1988. In the early years of program initiation, FCHVs were assigned to promote and distribute the family planning commodities such as condoms and pills. Over past three decades, FCHVs' roles have gradually expanded beyond family planning program and especially are focused on maternal and child health services at a large scale. FCHVs are an integral part of many community-based health programs, and their roles are instrumental in linking families and communities to community health workers and periphery-level health facilities. However, the fragmented nature of health programs poses a challenge for these health volunteers to coordinate activities and deliver the results. This perspective aims to review their contribution, challenges and recommend an integrated FCHV program model to support in the implementation of the community-based health interventions effectively.

Keywords: community-based, female community health volunteers, maternal and child health, Nepal, roles

\section{INTRODUCTION}

Female Community Health Volunteer (FCHV) program started in 1988. In the early years of program initiation, married women of reproductive age were selected as FCHVs and assigned to promote and distribute the birth-spacing commodities such as condoms and pills, with the sole purpose of supporting family planning program in Nepal. After almost three decades, these health volunteers have become an indispensable part of community-based health programs in Nepal (1, 2). Currently, over 52,000 FCHVs are actively working - roughly one in 500 people or at least one in each ward of Village Development Committee, the smallest local administrative body, as non-paid community health cadres (3). The current FCHV guideline has provisioned that the FCHVs must be married and reside in the ward where they are expected to serve. Mothers' group for health (a group of women active in different local social and health activities within their locality) selects them to work within their community. After selection, they get 18 days of basic training on family planning, maternal, newborns, child health, and nutrition issues (4). Earlier, the FCHVs were assigned to act as health promoters and dispensers of health commodities, but later with few exceptions, they are also serving as health service providers, notably treating childhood pneumonia and diarrhea at the community (5-7). 


\section{ROLES OF FCHVs IN COMMUNITY-BASED HEALTH PROGRAMS}

Female Community Health Volunteers are playing important roles in the implementation of many community-based maternal and child health programs such as National Immunization Program, Birth Preparedness Package, Community-Based Integrated Management of Neonatal and Childhood Illness (CB-IMNCI), Integrated Management of Acute Malnutrition, Infant and Young Child Feeding, and Family Planning program (3). In these programs, FCHVs are expected to accomplish several health activities in the community. Categorically, these activities can be divided into health promotion and dispensing of community health commodities, and treatment and referral services (6). For health promotion and dispensing works, they conduct mothers' group meetings, carry out counseling sessions on birth preparedness and complication readiness, distribute iron folate tablets to pregnant women, and distribute family planning commodities such as pills and condoms. They have also been mobilized to support the national campaigns like the national polio campaign and vitamin A capsule distribution to under-five children (4). As far as the treatment and referral role is concerned, FCHVs identify the childhood pneumonia and provide oral antibiotic (cotrimoxazole) if needed. In the event of childhood diarrhea, they provide zinc tablets and oral rehydration solution. Likewise, they also identify the danger signs in postpartum women and newborns during postnatal home visits and advise the new mothers for providing thermal care to the babies with low birth weight (8). The community health interventions which are implemented with the support of FCHVs, have had high population-level coverage, for instance, NDHS 2001, 2006, and 2011 (9-11) revealed that many interventions that are implemented through FCHVs had had in increasing trend and consistent population-level coverage (Table 1).

The remarkable progress on these indicators is mainly contributed by FCHVs who played pivotal roles in the dissemination of health information, and distribution of health commodities at the community level. Similarly, the annual health report based on Health Management Information System (HMIS) 2015 also reported that FCHVs treated about three of five childhood (aged under 5 years) diarrhea and pneumonia (12) (Table 1). However, the revised CB-IMNCI protocol 2014 (13) states that FCHVs are no longer eligible to treat childhood pneumonia in the community. This revision is supposed to affect the treatment of childhood pneumonia among many hard-to-reach, remote, and disadvantaged communities, where pneumonia is still a major cause of under-five deaths (13).

\section{CHALLENGES OF FCHVs PROGRAM}

Although the FCHVs have been making significant contributions to the health system of Nepal, this program is facing several challenges at the policy and implementation level. At the policy level, major challenges are about the ownership and verticalization of community components of health programs (14). The Family Health Division is responsible for the maternal health programs, for instance, Safe Motherhood Program and
Birth Preparedness Package. This division is also a focal point for FCHV program, where an officer is positioned to conduct FCHVs annual review meetings and maintain their profile (15). Similarly, the Child Health Division looks after Immunization, Nutrition, and CB-IMNCI programs (16). The major bulk of the FCHV's activities such as biannual supplementation of vitamin $A$ and deworming tablets to under-five children, iron tablets to pregnant women, actions against undernutrition, and other nutritional promotional campaigns at the community lies in the domain of Nutrition and CB-IMNCI programs (17). Most of the maternal and child health programs have separate community components for FCHVs. Furthermore, duplications are observed in the community activities between and within the programs of health divisions (18). For instance, neonatal health issues are included in the Child Health Division's CB-IMNCI program and Family Health Division's safe motherhood program. Likewise, nutritional contents such as treatment of malnutrition of underfive children and nutrition promotion are included in Child Health Division's CB-IMNCI and Nutrition programs (15). These kinds of duplications create the situation of vertical planning and management for the same program or similar purpose.

Also, because of programmatic fragmentations, FCHVs are found to be overburdened. As a result, they are obliged to perform multiple tasks for the similar activities listed in different programs (14). They are needed to train with separate action cards, job aids, treatment protocols, counseling guidelines and so forth for each community health program separately. In many situations, FCHVs become confused on different recording and reporting tools, and they face difficulties in filling up these forms $(14,16)$. It is to be noted that these volunteers are not highly educated and therefore putting a lot of recording and reporting burden on them might be detrimental to their volunteering actions $(14,19)$. Sometimes, these volunteers are also being used in other nonhealth programs such as forest users group, community development groups, education and microcredit and saving groups (14). It means that they have to spend more hours in other volunteer works beyond health sectors. Not surprisingly, therefore, there is a declining sense of motivation among the FCHVs being coupled with minimal event based incentives offered to them for their volunteer's support (20).

\section{INTEGRATED FCHV PROGRAM}

The Government of Nepal has acknowledged that the FCHVs have contributed significantly to achieve the milestones of the Nepal's Millennium Development Goals 4 and 5 by providing basic health services to women and children in the community. However, in the Sustainable Development Goal-era, their roles need some contextual modifications. They should be promoted as a bridge between families and communities to periphery-level health facilities but not as servicer providers with the exception in some remote areas. They can counsel mothers, dispense health commodities such as zinc, ORS, pills, or condoms, and refer women and children to the appropriate health workers or health facilities when needed (3).

Moreover, it is necessary to revitalize the FCHVs training curricula included in different community-based health programs. 
TABLE 1 | Female Community Health Volunteers (FCHVs) performance in community-based health programs.

\begin{tabular}{|c|c|c|c|c|c|c|}
\hline Health promotion and dispensing activities & $\begin{array}{l}\text { Number } \\
\text { (NDHS 2001) }\end{array}$ & $\begin{array}{c}\text { FCHV's } \\
\text { contribution } \\
\text { (\%) }\end{array}$ & $\begin{array}{c}\text { Number } \\
\text { (NDHS } \\
\text { 2006) }\end{array}$ & $\begin{array}{c}\text { FCHV's } \\
\text { contribution } \\
(\%)\end{array}$ & $\begin{array}{c}\text { Number } \\
\text { (NDHS } \\
\text { 2011) }\end{array}$ & $\begin{array}{c}\text { FCHV's } \\
\text { contribution } \\
(\%)\end{array}$ \\
\hline $\begin{array}{l}\text { Pregnant women received counseling on side effects } \\
\text { of family planning commodities }\end{array}$ & 2,952 & 66.4 & 1,471 & 55.5 & 1,533 & 64.6 \\
\hline Pregnant women received birth preparedness counseling & 4,745 & 47.6 & 4,066 & 57.3 & 4,148 & 75.5 \\
\hline Pregnant women received Iron tablets in the past 6 months & 4,745 & 22.7 & 4,066 & 59.3 & 4,148 & 79.5 \\
\hline Children (6-59 months) received vitamin A capsule & 6,293 & 81 & 4,768 & 87.5 & 4,360 & 90.4 \\
\hline $\begin{array}{l}\text { Children ( } 12-59 \text { months) received deworming tablets } \\
\text { in the past } 6 \text { months }\end{array}$ & 0 & 0 & 4,274 & 81.8 & 3,853 & 83.7 \\
\hline Health services and treatment provided & $\begin{array}{l}\text { Number } \\
\text { [HMIS 2013] }\end{array}$ & $\begin{array}{c}\text { FCHV's } \\
\text { contribution } \\
(\%)\end{array}$ & $\begin{array}{c}\text { Number } \\
\text { (HMIS } \\
\text { 2014) }\end{array}$ & $\begin{array}{c}\text { FCHV's } \\
\text { contribution } \\
(\%)\end{array}$ & $\begin{array}{c}\text { Number } \\
\text { (HMIS } \\
\text { 2015) }\end{array}$ & $\begin{array}{c}\text { FCHV's } \\
\text { contribution } \\
(\%)\end{array}$ \\
\hline $\begin{array}{l}\text { Children aged under } 5 \text { years with diarrhea treated with oral rehydration } \\
\text { solution and zinc }\end{array}$ & $1,753,758$ & 62 & $1,766,903$ & 64 & $1,413,111$ & 64 \\
\hline Children aged under 5 years with pneumonia treated with cotrimoxazole & $2,827,759$ & 57 & $2,671,922$ & 58 & $2,208,221$ & 57 \\
\hline
\end{tabular}

TABLE 2 | Contents of proposed integrated Female Community Health Volunteer program.

\begin{tabular}{|c|c|c|c|c|c|}
\hline $\begin{array}{l}\text { Prepregnancy } \\
\text { module }\end{array}$ & Prenatal module & Perinatal module & Postnatal module & Childhood module & Cross-cutting module \\
\hline $\begin{array}{l}\text { - Educating } \\
\text { women of } \\
\text { reproductive } \\
\text { age women on } \\
\text { family planning } \\
\text { - Counseling on } \\
\text { preconception } \\
\text { and maternal } \\
\text { nutrition during } \\
\text { prepregnancy } \\
\text { - Counseling } \\
\text { on hygiene } \\
\text { and sanitation } \\
\text { practices }\end{array}$ & $\begin{array}{l}\text { - Educating pregnant } \\
\text { women for promotion } \\
\text { of birth preparedness } \\
\text { and complication } \\
\text { readiness } \\
\text { - Promotion of ANC } \\
\text { care, tetanus toxoid, } \\
\text { and institutional } \\
\text { delivery } \\
\text { - Promotion of logo } \\
\text { iodized salt } \\
\text { - Dietary diversification } \\
\text { and promotion of } \\
\text { diversified food during } \\
\text { pregnancy } \\
\text { - Counseling on } \\
\text { promotion of maternal } \\
\text { micronutrient during } \\
\text { pregnancy } \\
\text { Counseling and } \\
\text { distribution of iron } \\
\text { foliate, calcium, } \\
\text { chlorhexidine gel, } \\
\text { misoprostol tablet }\end{array}$ & $\begin{array}{l}\text { - Promotion of clean and safe } \\
\text { delivery practices } \\
\text { - Promotion of hand washing } \\
\text { and sanitation activities } \\
\text { - Educating mothers on } \\
\text { essential newborn care } \\
\text { - Educating mothers on risk } \\
\text { of low birth weight babies, } \\
\text { advice for skin to skin } \\
\text { contact } \\
\text { - Counseling on complication } \\
\text { of non-breathing babies } \\
\text { at birth } \\
\text { - Counseling on exclusive } \\
\text { breastfeeding } \\
\text { - Counseling and distribution } \\
\text { of vitamin A, misoprostol } \\
\text { for prevention postpartum } \\
\text { hemorrhage in case of } \\
\text { home delivery, chlorhexidine } \\
\text { gel, iron folate tablets for } \\
\text { postpartum period }\end{array}$ & $\begin{array}{l}\text { - Educating mothers } \\
\text { on dangers signs of } \\
\text { postpartum mothers } \\
\text { and newborn and } \\
\text { referral if needed } \\
\text { - Counseling on } \\
\text { postpartum family } \\
\text { planning methods } \\
\text { - Counseling on } \\
\text { infant and young } \\
\text { child feeding and } \\
\text { complementary } \\
\text { feeding practices } \\
\text { - Promotion of child } \\
\text { growth monitoring } \\
\text { and childhood } \\
\text { immunization } \\
\text { - Nutrition education } \\
\text { on micronutrient, } \\
\text { dietary diversification, } \\
\text { and fortified food } \\
\text { vitamin A, iron folate } \\
\text { to mothers }\end{array}$ & $\begin{array}{l}\text { - Counseling and } \\
\text { identification of dangers } \\
\text { signs of common childhood } \\
\text { illness (pneumonia, diarrhea, } \\
\text { acute jaundice malnutrition) } \\
\text { and referral if needed } \\
\text { - Counseling on home-based } \\
\text { management of childhood } \\
\text { diarrhea and pneumonia } \\
\text { - Counseling and promotion } \\
\text { of childhood nutrition } \\
\text { interventions } \\
\text { - Counseling and promotion } \\
\text { of child immunization } \\
\text { - Distribution of vitamin A, } \\
\text { iron tablets, oral rehydration } \\
\text { packet, zinc tablets to } \\
\text { children } \\
\text { - Promotion and distribution } \\
\text { of condoms and pills } \\
\text { for eligible couple at the } \\
\text { community }\end{array}$ & $\begin{array}{l}\text { - Providing counseling on } \\
\text { prevention/protection } \\
\text { of other communicable } \\
\text { disease like HIV/AIDS } \\
\text { - Support other behavior } \\
\text { change communication } \\
\text { campaigns and social } \\
\text { activities } \\
\text { - Providing home health } \\
\text { education and advice on } \\
\text { diet and lifestyle } \\
\text { - Educating primary level } \\
\text { school students on } \\
\text { making healthy tiffin } \\
\text { and promoting healthy } \\
\text { canteen } \\
\text { - Providing information } \\
\text { on non-communicable } \\
\text { disease services } \\
\text { available at the health } \\
\text { facilities }\end{array}$ \\
\hline
\end{tabular}

Revitalization can be materialized with two approaches: first, the structural reform in the FCHVs program and second the integration of training curricula and programmatic contents into a single package. The organizational or structural reform could be the establishment of FCHVs unit including provision needed human resources at the various level of health organogram. Such unit would be responsible for planning and implementation of FCHVs based health interventions. And the integrated FCHV training curricula will help to reduce the work burden and harmonize the community health interventions. So, an integrated FCHV program can be designed in a continuum of care model-bringing all the prenatal, perinatal, and postnatal and child health training contents under a single umbrella. Such integrated program could also link the fragmented activities of community-based health programs in a continuum of care model (8) (Table 2).

In addition, given the changing epidemiological milieu in the country where non-communicable diseases (NCDs) are currently the leading cause of mortality and morbidity, they should be given some roles in disseminating health promotion messages on diet and lifestyles. Such integrated program including some roles on home-based health education for NCDs could mean an end to many vertical programs (Table 2). 


\section{CONCLUSION}

Female Community Health Volunteers are frontline pillars of community-based health programs in Nepal. They have been successful in making a significant contribution to various community-based maternal and child programs in various capacities as health promoters, dispensers, and service providers. However, the fragmented roles of FCHV program need to be reorganized comprehensively, structurally, and programmatically. It is crucial for the health authorities to craft an integrated FCHV program

\section{REFERENCES}

1. Shrestha S. A conceptual model for empowerment of the female community health volunteers in Nepal. Educ Health (Abingdon) (2003) 16(3):318-27. doi:10.1080/1357628031000701607668

2. Gurung SM, Justice J, Miller P, Gurung G. Diagnostic Assessment of the Female Community Health Volunteer Program in Nepal. Final Report. Kathmandu, Nepal (1992).

3. Ministry of Health and Population. Annual Report. Kathmandu, Nepal (2013).

4. Era N. An Analytical Report on Female Community Health Volunteers (FCHVs) of Nepal. Kathmandu: USAID/Government of Nepal (2007).

5. Shrestha S. Increasing contraceptive acceptance through empowerment of female community health volunteers in rural Nepal. J Health Popul Nutr (2002) 20(2):156-65.

6. Ministry of Population and Health, Department of Health Services, Family Health Division. National Female Community Health Volunteer Program Strategy (Draft, Third Revision). Kathmandu, Nepal (2007).

7. Curtale F, Siwakoti B, Lagrosa C, LaRaja M, Guerra R. Improving skills and utilisation of community health volunteers in Nepal. Soc Sci Med (1995) 40(8):1117-25. doi:10.1016/0277-9536(94)00172-P

8. Bhandari A, Pradhan YN, Kc NP, Upreti SR, Thapa K, Sharma G, et al. State of maternal, newborn and child health programmes in Nepal: what may a continuum of care model mean for more effective and efficient service delivery? J Nepal Health Res Counc (2011) 9(2):92-100.

9. Ministry of Health and Population (MOHP) [Nepal], New ERA, ICF International Inc. Nepal Demographic and Health Survey 2011. Kathmandu, Calverton, MA: Ministry of Health and Population, New ERA, and ICF International (2012).

10. Ministry of Health and Population (MOHP) [Nepal], New ERA, ICF International Inc. Nepal Demographic Health Survey 2006. Kathmandu, Calverton, MA: Ministry of Health and Population, New ERA, and ICF International (2007).

11. Ministry of Health and Population (MOHP) [Nepal], New ERA, ICF International Inc. Nepal Demographic and Health Survey, 2001. Kathmandu, Calverton, MA: Ministry of Health and Population, New ERA, and ICF International (2002). model and remove/merge the duplicated roles in various community-based maternal and child health programs. An integrated FCHV program can be cost effective community-based program package, which can increase FCHVs' productivity.

\section{AUTHOR CONTRIBUTIONS}

RK designed concept, review literature and drafted the paper. SM and VK provided support in revision. All the authors read the final version of the papers and approved it for publication.

12. Ministry of Health and Population. Annual Report. Kathmandu, Nepal (2015).

13. Ministry of Health and Population. CB-IMNCI Program Management Module. Kathmandu: Department of Health Services, Child Health Division (2015).

14. Ministry of Health and Population. Female Community Health Volunteer National Survey. Kathmandu: Department of Health Services, Family Health Division (2014).

15. Ministry of Health and Population. Annual Report. Kathmandu, Nepal (2014).

16. Child Health Division. Assessment of the Community Based Newborn Care Package. Kathmandu: Child Health Division, Ministry of Health and Population (2012).

17. Child Health Division, Family Health Division, Save the Children. A Synthesis of Recent Studies on Maternal and Newborn Survival Interventions in Nepal. Kathmandu: Child Health Division and Family Health Division, Ministry of Health and Population (2014).

18. Khatri RB, Mishra SR, Khanal V, Gelal K, Neupane S. Newborn health interventions and challenges for implementation in Nepal. Front Public Health (2016) 4:15. doi:10.3389/fpubh.2016.00015

19. Schwarz D, Sharma R, Bashyal C, Schwarz R, Baruwal A, Karelas G, et al. Strengthening Nepal's Female Community Health Volunteer network: a qualitative study of experiences at two years. BMC Health Serv Res (2014) 14(1):473. doi:10.1186/1472-6963-14-473

20. Swechhya B, Kamaraj R. Female community health volunteers program in Nepal: perceptions, attitudes and experiences on volunteerism among female community health volunteers. Int J Interdiscip Multidiscip Stud (2014) 1(5): $9-15$.

Conflict of Interest Statement: The authors declare that the research was conducted in the absence of any commercial or financial relationships that could be construed as a potential conflict of interest.

Copyright (c) 2017 Khatri, Mishra and Khanal. This is an open-access article distributed under the terms of the Creative Commons Attribution License (CC BY). The use, distribution or reproduction in other forums is permitted, provided the original author(s) or licensor are credited and that the original publication in this journal is cited, in accordance with accepted academic practice. No use, distribution or reproduction is permitted which does not comply with these terms. 